\title{
STRUCTURAL MODEL OF COUNSELING COMPETENCE
}

\author{
Arbin Janu Setiyowati ${ }^{1 *}$, Marthen Pali ${ }^{2}$, Bambang Budi Wiyono ${ }^{3}$ \\ and Triyono Triyono ${ }^{4}$ \\ ${ }^{1,3,4}$ Faculty of Education, Universitas Negeri Malang \\ ${ }^{2}$ Faculty of Psychology, Universitas Pelita Harapan Surabaya \\ *e-mail: arbin.janu.fip@um.ac.id
}

\begin{abstract}
Counseling competence is a set of essential abilities which is prominent to be employed in conducting counseling. This counseling competence research took students of counseling as a counselor candidate. This study aims to analyze the correlation between basic knowledge, basic communication skill, and cultural skill to the counseling competence. This work used Ex Post Facto Causal Relationship Explanatory research design. The research subjects were 120 students of Department of Guidance and Counseling from three State Universities in Java Island. Samples were taken by using cluster random sampling technique. The data analysis was conducted through Structural Equation Modeling (SEM) technique. The research results show that there is a significant relationship between knowledge, basic attitude, basic communication skill and cultural skill to the counseling competence. The implication of this research finding to the education of the Department of Guidance and Counseling is the significance of considering the factors forming the academic counseling competence to produce the professional counselor candidate.
\end{abstract}

Keywords: basic knowledge, basic attitude, basic communication skill, cultural skill, counseling competence

\section{MODEL STRUCTURAL MODEL KOMPETENSI KOUNSELING}

Abstrak: Kompetensi konseling merupakan seperangkat kemampuan yang mutlak dimiliki oleh konselor dalam menjalankan pelayanan konseling. Penelitian model kompetensi konseling ini dilakukan terhadap mahasiswa calon konselor. Penelitian ini bertujuan untuk menganalisis hubungan pengetahuan dasar, sikap dasar, keterampilan dasar komunikasi, dan keterampilan budaya dengan kompetensi konseling. Rancangan penelitian yang digunakan adalah Expost Facto Causal Relationship Explanatory. Subjek penelitian adalah mahasiswa jurusan Bimbingan dan Konseling (BK) dari tiga PTN di pulau Jawa sejumlah 120 orang. Penarikan sampel dilakukan dengan teknik cluster random sampling. Teknik analisis data menggunakan Structural Equation Modeling (SEM). Hasil penelitian menunjukkan adanya hubungan yang signifikan antara pengetahuan, sikap dasar, keterampilan dasar komunikasi, dan keterampilan budaya dengan kompetensi konseling. Implikasi temuan penelitian ini terhadap pendidikan S1 Bimbingan dan Konseling adalah pentingnya memperhatikan faktorfaktor pembentuk kompetensi konseling akademik sehingga mampu melahirkan calon konselor yang profesional.

Kata Kunci: pengetahuan dasar, sikap dasar, keterampilan dasar komunikasi, keterampilan budaya, kompetensi konseling

\section{INTRODUCTION}

Counseling process will run well if the counselor as the holder of a counseling service has sufficient counseling skill. The counseling process can be seen not only from the aspect of the counselees, their problems, and their environment support but also from the aspect of counselor since counseling process is expected to be able to be a therapeutic process for the student. 
The therapeutic process can be realized well only by a counselor having a sufficient counseling competence.

The counseling competence is an important thing that must be mastered by counselor because 1) counseling competence is a set of skill that must be owned by a counselor in conducting the counseling service, 2) counseling competence can help the counselor to facilitate the student to reach the selfdevelopment as optimally as possible, 3) counseling competence can support the qualified counseling service and give benefit for everyone especially for student, and 4) the development of counseling competence should be done continually to enhance the quality of counseling service as optimally as possible.

Developing the counseling competence of a counselor is begun since the counselor education. The educational curriculum of Undergraduate Program of Guidance and Counseling is designed in such a way to facilitate the counselor candidate-students in improving their competence as a counselor candidate especially the counseling academic competence. The counseling academic competence of a counselor candidate student is expected to be a basis for developing a high-quality counseling service when he/she becomes a counselor in a school. Therefore, it is necessary to identify the factors forming the counseling academic competence of the counselor candidate-student.

Knowledge is one of the principal domains in counseling competence (Bates \& Stevenson, 1998; Egbochuku, 2010; Greenberg, Watson, Elliot, \& Bohart, 2001; Kastberg, Jordan, Kiweewa, \& Clingerman, 2014; Lee, 2002; Reinkraut, Motulsky, \& Ritchie, 2009). Knowledge is the main asset for a counselor in conducting the counseling. The counselor's knowledge of counseling and its aspects will navigate the counselor during the counseling process. The knowledge will help the counselors to have a comprehensive understanding of the counseling process so that they can optimally prepare themselves for counseling service. One of the factors causing failure of counseling process experienced by some counselors is the counselor's knowledge. NCGE (2011) viewed that knowledge becomes the basis for counselor in developing their professional competence, especially for the counseling aspect. Knowledge becomes the basis to hold the counseling service that can prosper the serviced counselee. The variable of basic knowledge in this research refers to the concept developed by ASCA (2012); Depdiknas (2008); and NCGE (2011). The knowledge of counseling includes the knowledge of principle, method, and counseling procedure.

The basic attitude orients to the attitudes needed and contributing to the counseling process. The counselor is expected to have the attitudes that can emerge the awareness and willingness of counselee to be engaged actively in the counseling process. The counselor's basic attitude will show how great the counselors' willingness to perform themselves entirely in the counseling process. The intact engagement of counselor in the counseling process is very important to make the counseling a therapeutic process.

The counselor's basic attitude influences the counseling competency significantly (Cornelius-White \& Carver, 2012; Dollarhide, Shavers, Baker, Dagg, \& Taylor, 2012; Moon, 2007; Ridge, Campbell, \& Martin, 2003; Trusty \& Brown, 2005; Wampold, 2011; Wilkins, 2000). In humanistic view, a counselor should have some attitudes to realize an effective counseling process; they are 1) Congruence; 2) Unconditional positive regard; 3) Empathic understanding (Rogers, 1957), and 4) Trust (Corey, 2013). The counselor should have the basic attitude to facilitate the counselee's development. The four conditions do not 
naturally happen to the counselor but they should emerge continually in a helping relationship.

The counselor should use facilitating response when communicating with the counselee to reach the purpose of counseling. Generally, the response is classified into communication skill entirely. The good basic communication skill will help the counselee to understand well the counseling process so that he/she can feel the benefit of the counseling. The basic communication knowledge influences the counseling competency significantly ( Barone, Hutchings, Kimmel, Traub, Cooper \& Marshall, 2005; Bernes, 2005; Egbochuku, 2010; Fox, 2005; Mancillas, 2006; Sawyer, Peters, \& Willis, 2013). A counselor who Hairhas a sufficient communication skill will be able to facilitate the reach of feeling, knowledge, way of rational thinking and client's behavior changes helped by using certain counseling approach. The good communication skill mastery will be a foundation to be able to listen effectively so that the counselor can help the counselee to change and grow up as a genuine person (Ivey, Ivey, \& Zalaquett, 2013). Ivey et al., (2013) said that there are three communication skills that should be mastered by the counselor in the counseling process; they are attending behavior, listening skill and influencing skill.

The therapeutic relation will grow up and develop in the counseling process if the counselor can position the counselees equally to solve their problems. The counselor should always see the counselees as an individual having potential and who can use their potential to solve their problems. The counselor should build a positive relationship with the counselees to facilitate them to be aware of and use their potential well.

The positive correlation with counselee occurs due to the counselor's awareness to realize that counselee comes by bringing a set of multiple values/culture
(Sue, Arredondo, \& McDavis, 1992). The set of the diverse culture in the counseling process demands the counselor's extra caring and understanding. Counseling process will run well and comprehensively if the counselor can well understand the counselee so that the counselee feel comfortable and can be themselves in the counseling process. The most important thing in the counseling relationship is the counselor together with the counselee realizing the therapeutic change (Lubis, 2011).

Cultural skill is a continual and multi-layers process involving the personal, interpersonal and organization in the wider level (Hogan, 2012). There are four aspects related to the cultural skill namely the culture as the multilevel and multidimensional, cultural inhabitation, culture centered-communication skill, design and implementation of cultural organization.

The above explanation shows that there is a contribution of basic knowledge, basic attitude, and basic communication skill, and cultural skill to the quality of counseling. Some research that has been previously conducted only studied the contribution of each variable to the quality of counseling separately. The research on the relationship between those variables with the counseling competence has not been conducted. Hence, the study to see the contribution and correlation between four variables to the counseling competence forming is essential to conduct.

This research on counseling competence model was carried out to the counselor candidate-students. These students were chosen since the pre-service education is the basis for forming the counselor candidate's competence. The inappropriate counseling practices in the field are possibly influenced, among others by the pre-service education. The selection of the research subject is expected to contribute to revise the curriculum of pre- 
service education at Program of Guidance and Counseling.

\section{METHODS}

\section{Research design}

The design of the study concerning the structural relations model between basic knowledge, basic attitudes, basic communication skills, and cultural skills with competency counseling was correlational research. Based on the relationship among variables, this study was included in Ex-post Facto Causal Relationship Explanatory Study. This research did not merely explain the relationship, but, more than that, it was to explain the level of influence among variables. This research was in the position of a comparative causal relationship because one variable strongly influences the other variables, one variable depends on the other variable, one variable determines the other variable, one variable requires another variable.

\section{Population and Samples}

The study population was taken from six state universities in Java that administer Undergraduate Degree in Guidance and Counseling, which previously were Institut Keguruan dan Ilmu Pendidikan (IKIP). The six state universities are in different cities in Java Of the six state universities, three state universities were selected as research samples using cluster stratified random sampling.

This study chose the seventh semester of Guidance and Counseling students. The reason for choosing 7thsemester students was since they have taken the entire counseling classes, and already have experience in counseling practice with both peers and real counselees. The study population was 253 students of 2013 batch from the three state universities. The samples were taken by using cluster random sampling technique, resulting 120 participants.

\section{Instrument}

The instrument used to collect the data of knowledge, basic attitude, basic communication skill, cultural skill was scale in the form of reflection. Four instruments used had fulfilled the requirement of validity and reliability as the instrument of data collection. The four scales have good construct validity of $(\mathrm{KMO}>0.500, \mathrm{MSA}>0.500$ and loading factor > 0.300). The scores of alpha Cronbach were 0.714 for basic knowledge, 0.623 for basic attitude, 0.650 for basic communication skill, and 0.727 for cultural skill. It means that all scales were reliable since the scores of alpha Cronbach $>0.60$. Each statement in the research instrument was assessed by using the differential semantic scale in which two different poles exist. The negative pole was given the score of 1 and the positive pole was given the score of 5 . The counseling competence assessment used the data of the score of individual and group counseling practices.

\section{Data Analysis}

This research used structural equation modeling (SEM) analysis technique with Amos of 22.0 version software. The SEM analysis was conducted in seven main steps as follows: (1) Model development based on concept and theory. (2) Path Diagram development, (3) Path diagram conversion to structural model (statistics equation), (4) Determining input matrix and model estimation, (5) Examining identification problem, (6) Evaluating goodness of fit, (7) Interpreting and modifying the model

\section{FINDINGS AND DISCUSSION Findings}

Some following tests should be undertaken to do analysis by using structural equation modelling (SEM) and obtain some assumptions that should be fulfilled. 


\section{Evaluating Sample Size}

The number of samples in testing with SEM is recommended at least 50 and not more than 400-500. In this study, the number of samples used was 120 respondents hence they met the minimum number of samples for testing.

\section{Normality Test}

Data normality is one of the requirements in SEM. The normality test is emphasized on the multivariate data by seeing the score of skewness, kurtosis and by seeing the critical ratio (CR) score statistically. If the significance level used was $5 \%$, so the CR score was in the range of -2.58 up to $2.58(-2.5<\mathrm{CR}<2.58)$ and the data is stated as normally distributed both in univariate and multivariates, so the data categorized as normally distributed that would be analyzed in the next step. The analysis results show that most of the indicators in univariate and multivariates gained the score of CR between -2.58 to +2.58 so that the normality assumption was fulfilled in univariate.

\section{Outliers Test}

The outliers' assumption testing was conducted by using Mahalanobis Distance test showing how far the distance of one data from a certain center point. The criterion that was used was by using the score of Mahalanobis D-Square (MD). The analysis results yielded the score of Mahalanobis d-squared was less than the value of chi-square of 117.632 . This result showed that there was no observation included in outliers so that the assumption was confirmed.

\section{Uni-dimensionality Test}

The uni-dimensionality analysis was done by using confirmatory factor analysis. In this analysis, the validity level of each indicator was tested by comparing the value of CR to T-Tabel based on the error level of alpha which was 5\% (0.05). If the score of CR was more than T-Tabel (1.960), it can be concluded that the lambda coefficient of the indicator is valid and vice versa. The lambda coefficient of each indicator which was greater than 0.500 showed that the indicator was valid. The analysis result of every latent variable attained the loading factor of each indicator that was more than 0.500 and the probability score of t-statistic which was less than 0.050 meaning that each indicator could well form the latent variable (valid).

\section{Evaluation of Model Feasibility Criteria}

Evaluation of the model correctness that basically has been done on the model estimated will result in parameter number that will be compared to the cut-off value of the goodness of fit. Hair, Black, Babin, Anderson, \& Tatham (2006) stated that not all criteria are used to know the fit of a certain model; it is enough by fulfilling the requirement to avoid redundancy. The criteria used at least include $\chi^{2}$, df, and pvalue, one absolute index (GFI, RMSEA, SRMR), one index of Goodness-of-fit (GFI, CFI, TLI, or the others) and one index of the badness of fit (RMSEA, SRMR).

Based on Table 1, the results of the SEM goodness of fit is available. Chisquare statistics followed statistical tests which were related to significant requirements, where the smaller the chisquare value, the better the suitability of the model with data and $p$-value $\geq 0.05$. The overall model fit test in this study obtained a chi-square of 185.609. The measure of goodness of fit in this model, chi-square obtained a $p$-value $=0,000 \geq$ 0,050 thus it can be said the model has a fewer goodness of fit. The results only show that there is one measure of goodness of fit showing good compatibility which hence it is necessary to adjust the model. 
Table 1. The Result of Initial Step of Model Feasibility Test

\begin{tabular}{cccc}
\hline $\begin{array}{c}\text { Goodness } \\
\text { of Fit }\end{array}$ & $\begin{array}{c}\text { Test } \\
\text { Score }\end{array}$ & Criteria & Note \\
\hline $\begin{array}{c}\text { Chi-square } \\
(\chi 2)\end{array}$ & 185.609 & Small & Poor Fit \\
p-value & 0.000 & $>0.050$ & Poor Fit \\
CMIN/DF & 1.875 & $<2.000$ & Good Fit \\
RMSEA & 0.086 & $<0.080$ & Marginal Fit \\
GFI & 0.855 & $>0.900$ & Marginal Fit \\
AGFI & 0.801 & $>0.900$ & Marginal Fit \\
TLI & 0.858 & $>0.950$ & Marginal Fit \\
CFI & 0.883 & $>0.950$ & Marginal Fit \\
\hline
\end{tabular}

Table 2. The Result of the Last Step of Model Feasibility Test

\begin{tabular}{cccc}
\hline $\begin{array}{c}\text { Goodmess } \\
\text { of Fit }\end{array}$ & $\begin{array}{c}\text { Test } \\
\text { Score }\end{array}$ & Criteria & Note \\
\hline $\begin{array}{c}\text { Chi-square } \\
(\chi 2)\end{array}$ & 80.844 & Small & Good Fit \\
p-value & 0.515 & $>0.050$ & Good Fit \\
CMIN/DF & 0.986 & $<2.000$ & Good Fit \\
RMSEA & 0.000 & $<0.080$ & Good Fit \\
GFI & 0.930 & $>0.900$ & Good Fit \\
AGFI & 0.883 & $>0.900$ & Marginal Fit \\
TLI & 1.002 & $>0.950$ & Good Fit \\
CFI & 1.000 & $>0.950$ & Good Fit \\
\hline
\end{tabular}

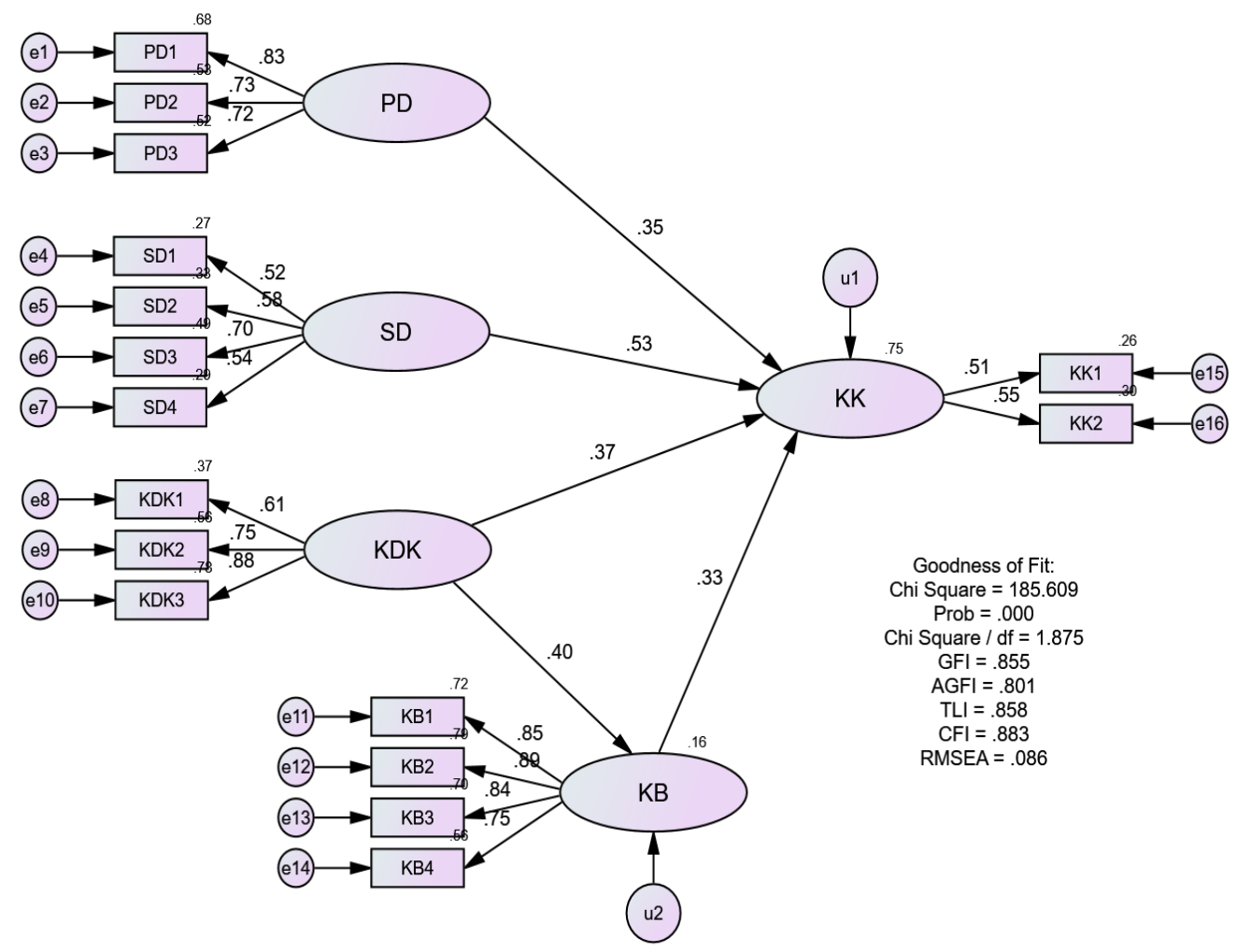

Figure 1. Initial Step of Conceptual Model

Based on Figure 1, the analysis results show that there is no criterion of goodness of fit fulfilled so that the model adaptation should be conducted by doing a modification with the modification indices.

Based on Table 2, it can be seen the results of the SEM model feasibility test. The overall test in this study obtained a chi-square of 80.844 . Chi-Square statistics followed statistical tests related to significant requirements, where the smaller the chi-square value, the better the suitability of the model with data and pvalue was $\geq 0.05$. The Goodness of fit size in this model, chi-square obtained a pvalue $=0,515 \geq 0.050$, it can be said that the model has a good fit. The model test results indicate there are seven sizes 
showing good fit and one other size showing poor compatibility. Most tests confirm fit regarding the models, it can be concluded that the model used in this study can be used as the basis of the analysis of the problems of this study.

According to Figure 2, the analysis results show all criteria of goodness of fit fulfilled so that the model is feasible to use. If the last model is described generally by showing the line coefficient of basic knowledge, basic attitude, basic communication skill, and cultural communication, the counseling competency will be seen as presented in Figure 3.
Based on Figure 3, it can be explained the theoretical models are related to counseling competencies. That is how one construct relates to another construct. Counseling competencies are shaped by basic knowledge, basic attitudes, basic communication skills, and cultural skills. The results showed that the empirical conceptual counseling competency model was declared fit or fulfilled with the fulfilment of the criteria value $\chi 2<$ critical value; $p$-value $=0.515>$ critical value $0.050 ; \mathrm{GFI}=0.930>$ critical value 0.900 and RMSEA $=0,000<$ critical value 0.080 .

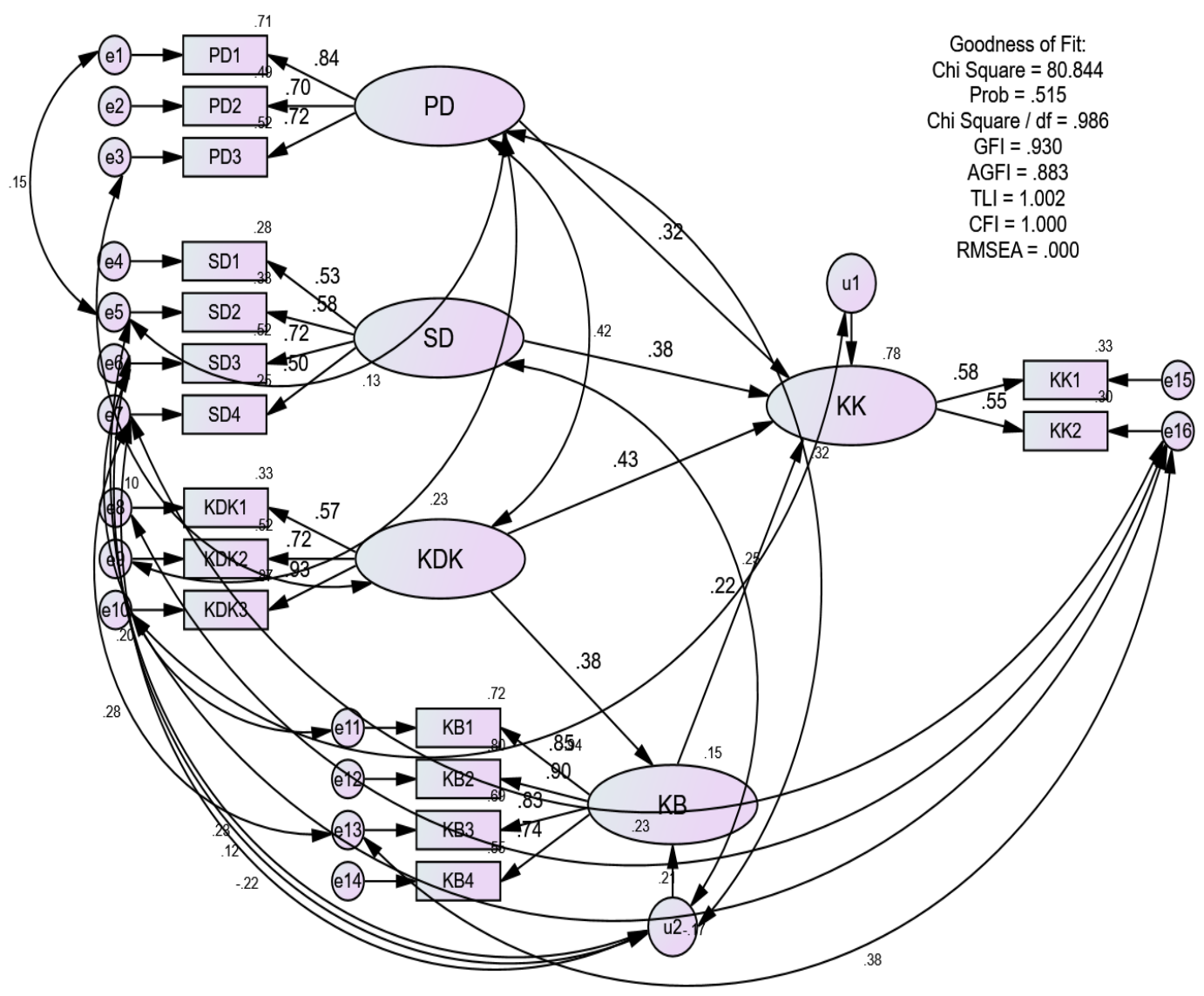

Figure 2. Conceptual Model After Modification 


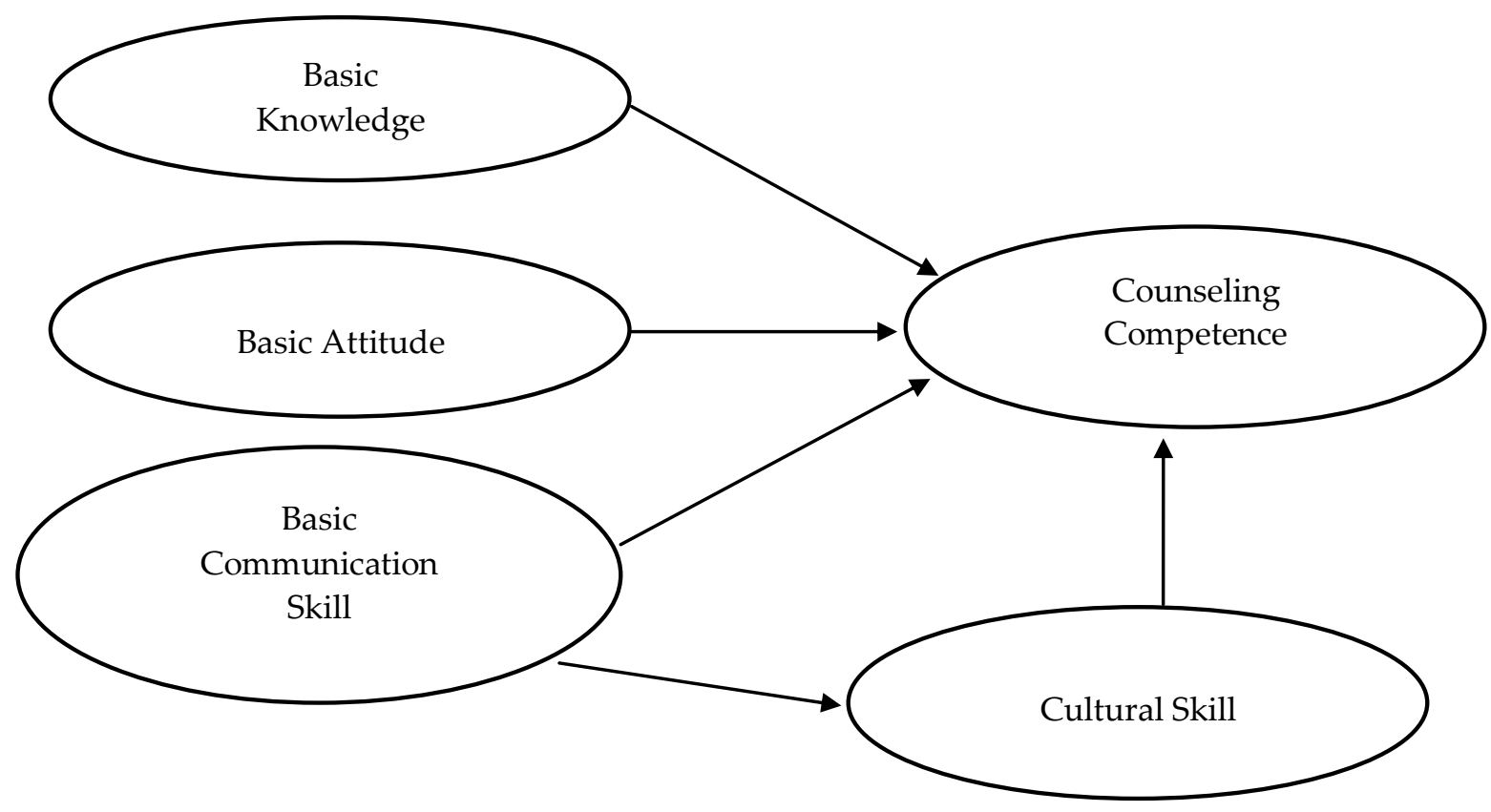

Figure 3. The Line Diagram of the Correlation between Basic Knowledge, Basic Communication Skill and Cultural Skill to the Counseling Competence

To evaluate the feasibility of the measurement model, that is through evaluating the validity and evaluation of reliability. The following will explain the results of the evaluation. A variable is said to have good validity for the construct or latent variable if the value of the $t$ factor (loading factors) is greater than the critical value (or $\geq 1.96$ or practically $\geq 2$ ) and the standardized loading factor $\geq 0.70$. And said to be reliable if $\mathrm{CR} \geq 0.70$ and $\mathrm{VE} \geq$ 0.50. The following Table 3 shows the results of the evaluation of the validity and reliability of each latent variable or indicator.

Based on Table 3, construct reliability of the entire latent variables are higher than 0.700 and the variance extract are higher than 0.500. Thus the entire variables have fulfilled construct reliability and variance extracted.
Table 3. Reliability Test of Constructs and Variance Extract

\begin{tabular}{lcc}
\hline \multicolumn{1}{c}{ Variable } & $\begin{array}{c}\text { Construct } \\
\text { Reliability }\end{array}$ & $\begin{array}{c}\text { Variance } \\
\text { Extract }\end{array}$ \\
\hline Basic & 0.940 & 0.840 \\
Knowledge & 0.889 & 0.670 \\
$\begin{array}{l}\text { Basic Attitude } \\
\text { Basic }\end{array}$ & 0.933 & 0.825 \\
$\begin{array}{l}\text { Communication } \\
\text { Skill }\end{array}$ & 0.968 & 0.883 \\
$\begin{array}{l}\text { Cultural Skill } \\
\text { Counseling } \\
\text { Competences }\end{array}$ & 0.736 & 0.583 \\
\hline
\end{tabular}

\section{Structural Model}

We can see the following structural model equation to know the correlation between the studied variables. This equation is designed to state the causality correlation between the constructs. In this part, the equation between variables of basic knowledge, basic attitude, basic communication skill, cultural skill and counseling competence are formed. 
$\mathrm{CC}=\beta_{1} \mathrm{BK}+\beta_{2} \mathrm{BA}+\beta_{3} \mathrm{BCS}+\beta_{4} \mathrm{CS}+\mathrm{u}_{1}$ $\mathrm{CC}=0.350 \mathrm{BK}+0.531 \mathrm{BA}+0.372 \mathrm{BCS}+$ $0.333 \mathrm{CS}+0.014$

From the equation above, we know that the variable of basic attitude is a dominant variable having the direct correlation to the counseling competency with the biggest coefficient that was 0.531 . It means that the counseling competence was dominantly formed by the variable of basic attitude.

\section{Indirect and Direct Influence}

From the calculation result through confirmatory factor analysis and Structural Equation Modelling, the model of this research can be accepted. Furthermore, Table 4 presents the analysis result of direct, indirect and total influences.

Table 4. The Result of Direct and Indirect Influences

\begin{tabular}{cccc}
\hline \multirow{2}{*}{ Influence } & \multicolumn{3}{c}{ Coefficient } \\
\cline { 2 - 4 } & Direct & Indirect & Total \\
\hline $\mathrm{PD} \rightarrow \mathrm{CC}$ & 0.350 & - & 0.350 \\
$\mathrm{BA} \rightarrow \mathrm{CC}$ & 0.531 & - & 0.531 \\
$\mathrm{BCS} \rightarrow \mathrm{CS}$ & 0.404 & - & 0.404 \\
$\mathrm{BCS} \rightarrow \mathrm{CC}$ & 0.372 & 0.135 & 0.507 \\
$\mathrm{CS} \rightarrow \mathrm{CC}$ & 0.333 & - & 0.333 \\
$\mathrm{PD} \rightarrow \mathrm{CC}$ & 0.350 & - & 0.350 \\
$\mathrm{BA} \rightarrow \mathrm{CC}$ & 0.531 & - & 0.531 \\
\hline
\end{tabular}

Based on Table 4, it is known that there are five direct influence coefficients and one indirect influence coefficient. The direct influences generated are (1) the influence of basic knowledge with counseling competencies with a coefficient of 0.350 , (2) the influence of basic attitudes with counseling competencies with a coefficient of 0.531 , (3) the influence of basic communication skills with cultural skills with a coefficient of
0.404, (4) the influence of basic communication skills with counseling competencies with a coefficient of 0.372 , and (5) the influence of cultural skills with counseling competencies with a coefficient of 0.333 . The indirect influence generated is the relationship of basic communication skills with counseling competencies through cultural skills with a coefficient of 0.135 .

\section{The Correlation between Average Score and Loading Factor}

The relationship between the average score and the loading factor is used to determine the conformity between the average score and the loading factor for each variable.

\section{Loading Factor and Average Score of Basic Knowledge \\ Basic Knowledge Variables are} formed by three dimensions, namely (1) Principles of Counseling, (2) Counseling Methods, and (3) Counseling Procedures. The relationship between the average score and the value of loading factors is presented in Table 5.

The results of the relationship between the average score and the value of loading factors on basic knowledge variables indicate that, based on the average respondent, the most of the subject provided positive response to basic knowledge variable through the dimensions of counseling principles and based on loading factors the counseling principle is the indicator that best reflects basic knowledge variables.

Table 5. Loading Factor and Average Score of Basic Knowledge

\begin{tabular}{rccc}
\hline Variable & Dimension & Average Score & Loading Factor \\
\hline \multirow{3}{*}{ Basic Knowledge } & PD1 & $\mathbf{3 . 9 5 1}$ & $\mathbf{0 . 8 2 7}$ \\
& PD2 & 3.567 & 0.726 \\
& PD3 & 3.672 & 0.724 \\
\hline
\end{tabular}


Table 6 Loading Factor and Average Score of Basic Attitude

\begin{tabular}{|c|c|c|c|}
\hline Variable & Dimension & Average Score & Loading Factor \\
\hline \multirow{4}{*}{ Basic Attitude } & SD1 & 3.847 & 0.519 \\
\hline & $\mathrm{SD} 2$ & 3.827 & 0.575 \\
\hline & SD3 & 3.794 & 0.703 \\
\hline & SD4 & 3.936 & 0.536 \\
\hline \multicolumn{4}{|c|}{ Table 7. Loading Factor and Average Score of Basic Communication Skills } \\
\hline Variable & Dimension & Average Score & Loading Factor \\
\hline \multirow{3}{*}{ Basic Communication Skills } & KDK1 & 4.025 & 0.609 \\
\hline & KDK2 & 3.675 & 0.750 \\
\hline & KDK3 & 3.604 & 0.882 \\
\hline
\end{tabular}

Table 8. Loading Factor and Average Score of Cultural Skills

\begin{tabular}{cccc}
\hline Variable & Dimension & Average Score & Loading Factor \\
\hline \multirow{4}{*}{ Cultural Skills } & KB1 & 3.815 & 0.850 \\
& KB2 & 3.892 & $\mathbf{0 . 8 9 0}$ \\
& KB3 & 3.977 & 0.839 \\
& KB4 & $\mathbf{4 . 0 0 2}$ & 0.751 \\
\hline
\end{tabular}

Table 9. Loading Factor and Average Score of Counseling Competence

\begin{tabular}{cccc}
\hline Variable & Dimension & Average Score & Loading Factor \\
\hline \multirow{2}{*}{ Counseling Competence } & KK1 & $\mathbf{3 . 8 3 7}$ & 0.507 \\
& KK2 & 3.505 & $\mathbf{0 . 5 4 8}$ \\
\hline
\end{tabular}

Loading factors and the basic attitude value

Basic attitude variable is formed by four dimensions, namely (1) genuine, (2) unconditional positive regard, (3) empathic understanding, and (4) trust. The relationship between the average score and the value of loading factors is presented in Table 6.

The results of the relationship between the average score and the value of loading factors on the basic attitude variable indicate that, based on the average respondent, the response to basic attitude variables through trust dimensions wast mostly positive and based on the loading factor dimensions empathic understanding is an indicator that best reflects basic attitude variables.

Loading factors and the average score of Basic Communication Skills

Variables of Basic Communication Skills are formed by three dimensions, namely (1) attending behavior, (2) listening skills, and (3) influencing skills. The relationship between the average value and the value of loading factors is presented in Table 7.

The results of the relationship between the average score and the loading factor of the basic communication skills variable indicate that, based on the average respondents' response, most of them provided positive response to the variable communication skills through the dimension of attending behavior and based on the loading factor, influencing skills dimension serves as an indicator that best reflects basic communication skills.

\section{Loading factors and the average value of Cultural Skills}

Cultural skill variables are formed by four dimensions, namely (1) culture as multilevel and multidimensional, (2) managing cultural barriers, (3) communication skills centered on culture, 
and (4) designing and implementing organizational culture. The relationship between the average score and the value of loading factors is presented in Table 8 .

The results of the relationship between the average score and the loading factor on cultural skill variables indicate that most subjects provided a positive response to cultural skills variables through dimensions of designing and implementing organizational culture, and based on loading dimensional factors managing cultural barriers that best reflects cultural skills.

\section{Loading factors and the average score of Counseling Competence}

The competency counseling variable is formed by two indicators, namely (1) individual counseling practicum and (2) group counseling practicum. The relationship between the average value and the value of loading factors is presented in Table 9.

The results of the relationship between the average score and the loading factor for the Counseling Competence variable indicate that, based on the average respondents' response, most of them provided positive response to the counseling competence variable through individual counseling practicum dimensions and based on the loading factor, group counseling was the indicator that most reflects the Counseling Competence variable.

\section{Discussion \\ Correlation between Constructs}

Based on the result of data analysis, knowledge correlates directly, positively and significantly to the counseling competency. It means that basic knowledge has a major role in building the counselor candidate-students' counseling competence. The finding showing that the basic knowledge correlates positively, significantly and directly to the counseling competence supports the previous research that knowledge is one of the principal domains in counseling competence (Bates
\& Stevenson, 1998; Egbochuku, 2010; Greenberg, Watson, Elliot, \& Bohart, 2001; Kastberg, Jordan, Kiweewa, \& Clingerman, 2014; Lee, 2002; Reinkraut, Motulsky, \& Ritchie, 2009). The finding also suppoort of Swank, Lambie, \& Witta (2012) stating that counseling competence can be assessed from the professional behavior (the owned knowledge, the obedience to the rule, counseling policy, consultation activity), professional disposition (professional ethics, multicultural competency), counseling relationship and counseling skill, assessment and its application. This research also supports the previous research finding addressing that counseling cannot be separated from therapy modality or theoretical orientation (Hauser \& Hays, 2010; Nelson \& Neufeldt, 1996). It means that the aspect of counselor's knowledge about counseling theories is the basis of an effective counseling.

The basic attitude correlates directly, positively and significantly to the counseling competence and it is a variable giving the biggest contribution to the counseling competence building. It means that the basic attitude has a major role in building the counselor candidate-students' counseling competence. The finding showing that the basic attitude correlates positively, significantly and directly to the counseling competence supports the finding of previous research that the counselor's basic attitude influences the counseling competency significantly (Cornelius-White \& Carver, 2012; Dollarhide, Shavers, Baker, Dagg, \& Taylor, 2012; Moon, 2007; Ridge, Campbell, \& Martin, 2003; Trusty \& Brown, 2005; Wampold, 2011; Wilkins, 2000). This finding research also support the finding of Hauser \& Hays (2010), Horvath (2000), Swank, Robinson, \& Ohrt (2012), Yager \& Tovar-Blank (2007); and correlates positively to the outcome of counselee (Elliott, 2008; Farber \& Doolin, 2011; Greenberg et al., 2001; Leibert \& 
Dunne-Bryant, 2015). The finding of this research also strengthens the previous research findings about the significant domain of the common factor of the effective therapy is therapeutic alliance (Wampold \& Budge, 2012) in which the relationship of counselee-counselor is included (empathy, report, non-judgement attitude, and trust), (Brown, Holloway, Akakpo, \& Aalsma, 2014; Sweeney et al., 2014).

The research finding showed that the basic communication skill correlates directly, positively and significantly to the counseling competence. It means that the basic communication skill has a major role in building the counselor candidatestudents' counseling competency. This research finding supports the previous research that the basic communication knowledge influences the counseling competency significantly (Barone et al., 2005; Bernes, 2005; Egbochuku, 2010; Fox, 2005; Mancillas, 2006; Sawyer, Peters, \& Willis, 2013).. This research finding supports the finding of Owen \& Hilsenroth (2014) concluding that therapist skill (counseling skill) and theoretical expertise set aside with the proper adaptation will be more effective to change the counselee. This finding is strengthened by Adigwe \& Okoro (2016) stating that communication skill is the significant part of the successful counseling practices. This finding shows the fact that the counselor candidatestudents must master the basic communication skill well to create an effective counseling relationship. The expertise of psychotherapy practice is defined as a manifestation of the highest level of ability, skill (Tracey, Wampold, Goodyear, \& Lichtenberg, 2015), professional competence and effectiveness (Hill, Spiegel, Hoffman, Kivlighan, \& Gelso, 2017).

The research finding exhibited that the basic communication skill correlates indirectly to the counseling competency through cultural skill. This research finding uncovered the fact that the basic communication skill of counselor candidate-students contributes to the counseling competence supported by cultural skill mastery. Cultural competence can be classified in the paradigm of communication (Hladík, 2014). In this paradigm, the cultural competence plays a dominant role in the communication process. It means that the basic communication skill mastery must be hand-in-hand with the cultural skill mastery in building the counseling competence. The interpersonal communication skill is an essential thing in the helping relationship. The crossculture counseling needs more than merely communication skill. The combination of cultural and relational skill with microskill training is the best way to accomplish the need of various counseling needs (Hall, Barden, \& Conley, 2014).

In the counseling process, the counselor's communication skill is one of the factors influencing the counseling success. However, if the counselor does not have the sufficient knowledge and cultural skill, the counseling process is possibly obstructed. The knowledge and understanding of cultural factors such as value, attitude, belief, and behavior are urgently needed to create a successful cross-culture communication (Gitimu, 2005). The counselors should learn the knowledge and understanding of cultural factors since, in their interaction with the counselee, they must face cultural differences. If the differences are not anticipated well, they will hamper the change process of the counselee. Ethnocentrism problem that is viewing the own culture is better than the others' culture is one of the obstacles that usually faced in the cross-cultural communication (Zaharna, 2000). Besides, the cultural obstacles in the counseling process are not merely the language difference, but also the difference in belief and even in understanding the disease and these things that cause problems in the cross-cultural 
communication (Van Wieringen, Harmsen, \& Bruijnzeels, 2002).

Based on the result of data analysis, the cultural skill correlates directly, positively and significantly to the counseling competency. It means that the cultural skill has a major role in building the counselor candidate-students' counseling competency. This research finding supports the previous research that the positive correlation with counselee occurs due to the counselor's awareness to realize that counselee comes by bringing a set of multiple values/culture (Sue et. al, 1992). The set of the diverse culture in the counseling process demands the counselor's extra caring and understanding. This research finding supports the finding of Hays (2016), Penn \& Post (2012), Sue \& Sue, (2012) addressing that multicultural competency gives significant impact on the outcome of the counselee. This finding indicates that counselor as a professional practitioner should be experienced in helping the counselee coming from various background (Collins \& Arthur, 2010; Bunu, 2016) so it is a must for a counselor to master the cultural skill. The importance of counselor's cultural skill is shown by the study of Constantine (2002) and Fuertes \& Brobst, (2002) finding that the counselor's multicultural skill is a variant supporting the satisfaction level of the minority of counselee significantly. Besides, showing the cultural skill mastery when interacting with the counselee can strengthen the work alliance and support to realize a positive therapy experience (Fuertes et al., 2006; Inman, 2006).

It can be concluded that knowledge, basic attitude, basic communication skill and cultural skill correlate significantly to the counseling competence. The big contribution is indicated by the high coefficient of SEM. The greatest contribution or influence was given respectively by 1) basic attitude which was 0.531 ; 2) basic communication skill which was 0.372 ; 3) knowledge which was
0.350; and 4) cultural skill which was 0.333 . It means that the higher/better the basic attitude, basic communication skill, knowledge and cultural skill, the counseling competence will increase as well.

\section{The Implication for Pre-Service Education of Guidance and Counseling Undergraduate Program}

This research of counseling competence model results in assessment instrument to assess each research construct. The assessment instrument of counseling competence model (consisting of the instrument of basic knowledge, basic communication skill, and cultural skill) can be used as facility and opportunity by the counselor candidatestudents to get clear feedback of their personal and professional development as a counselor. The counselor candidatestudents can get specific feedback on their power and the part that should be fixed through the assessed area. This case is in line with the statement of Bernard \& Goodyear (2009) about the opportunity for the counselor candidate-students to build their power and develop the area or potential that has not been explored yet. Besides, the instrument of this research can be used to facilitate the counselor candidate-students to develop their knowledge of counseling competency construct as well as learn the expectation to be performed in their counseling competence.

The instrument of counseling competence model can be used by the holder of counselor education program as one of the methods to evaluate the learning outcome of the counselor candidatestudents, especially regarding their counseling competence as well. Lecturers as a supervisor also can use this research instrument as the tool to help them regarding ethical and law responsibility and their roles as an educator, evaluator and the supervisor of counseling profession quality. 
The research results showed that the basic attitude is the variable mostly contributing to the counseling competence building. Basic attitude is a core condition facilitating the treatment process (Feller \& Cottone, 2003; Lambert \& Barley, 2001). It means that the counselor candidate absolutely should start to sharpen and train themselves to have a therapeutic personal attitude to facilitate the counselee's changing. A counselor' therapeutic personal attitude is a sufficient condition in the counseling process. The therapeutic effect is the result of counselee's experience change and especially changing the experience content should be the focus of an intervention (Hansen, 2007). Therefore, based on the result of this research, the effort of emerging the therapeutic personality of counselor candidate should be taken into account by giving the opportunity for every counselor to follow counseling session to decide all unfinished problems within themselves. The therapeutic personal attitude is expected to emerge naturally within counselor's personality by getting the counselee's personal experience. This case is supported by some research telling that more than $90 \%$ of psychotherapy receiving therapy report of the therapy outcome in the form of satisfaction and positive outcome from the therapy experience (Orlinsky \& Rønnestad, 2005).

The counselor candidate-students who have good counseling competence have a big opportunity to grow up becoming a counselor prioritizing a save counseling practice and giving benefit to counselee's growth and development. A competent counselor is urgently needed to respond the more complex life and the problem of students that need a qualified professional help. This condition exactly needs a high-quality professional help from a counselor.

\section{CONCLUSION}

The research finding showed that 1) there is a significant correlation between basic knowledge, basic attitude, basic communication skill and cultural skill to the counseling competence. 2) The direct relationship between the variable of basic knowledge and the counseling competence of counselor candidate-students was significantly and positively found. 3) The direct relationship between the variable of basic attitude and the counseling competence of the counselor candidatestudents was significantly and positively found. 4) The direct correlation between the variable of basic communication skill and the counseling competence of the counselor candidate-students was significantly and positively found. 5) The indirect correlation between the basic communication skill and counseling competence of the counselor candidatestudents through the variable of cultural skill was significantly and positively found.

\section{ACKNOWLEDGMENT}

The authors would like to thank of the Ministry of Research, Technology, and Higher Education of Indonesia for their funding support of this research.

\section{REFERENCES}

Adigwe, P. \& Okoro, E. (2016). Human communication and effective interpersonal relationship: An analysis of client counseling and emotional stability. International Journal of Economic and Management Sciences, 5(3), 1-4. doi: 10.4172/2162-6359.1000336.

ASCA. (2012). ASCA school counselor competencies. Retrieved from https://www.schoolcounselor.org/asc a/media/asca/home/SCCompetencies .pdf.

Barone, D. F., Hutchings, P. S., Kimmel, H. J., Traub, H. L., Cooper, J. T., \& Marshall, C. M. (2005). Increasing empathic accuracy through practice and feedback in a clinical 
interviewing course. Journal of Social and Clinical Psychology, 24(2), 156-171. doi: 10.1521/jscp.24.2.156.62275.

Bates, M., \& Stevenson, P. (1998). Good counseling is just excellent communication skills! Or is it. Counseling Association of Australia Inc. Journal, 1(1), 5-7.

Bernard, J. M., \& Goodyear, R. K. (2009). Fundamentals of clinical supervision (4th ed.). UER Saddle River, NJ: Pearson.

Bernes, K. B. (2005). The elements of effective counseling. NATCON Papers. Retrieved from http://www.natcon.org http://hdl.handle.net/10133/1167.

Brown, J. R., Holloway, E. D., Akakpo, T. F., \& Aalsma, M. C. (2014). "Straight up": enhancing rapport and therapeutic alliance with previouslydetained youth in the delivery of mental health services. Community Mental Health Journal, 50(2), 193203. doi: 10.1007/s10597-013-96173.

Bunu, H. Y. (2016). Pemindaian penerapan bimbingan dan konseling dengan pendekatan multikultural di SMA. Jurnal Cakrawala Pendidikan, 35(3), 386-394. doi: 10.21831/cp.v35i3.8892.

Corey, G. (2013). Theory and practice of counseling and psychotherapy (9th ed.). Belmont, CA: Brooks/Cole.

Cornelius-White, J. H. D., \& Carver, C. L. (2012). Effects of an encounter group for counselors-in-training on development of person-centered core conditions. Hellenic Journal of Psychology, 9(3), 205-221.

Collins, S., \& Arthur, N. (2010). Cultureinfused counseling: A fresh look at a classic framework of multicultural counseling competencies. Counseling Psychology Quarterly, 23(2), 203-216. doi: $10.1080 / 09515071003798204$.

Constantine, M. G. (2002). Predictors of Satisfaction with counseling: racial and ethnic minority clients' attitudes toward counseling and their ratings of their counselors' general and multicultural counseling competence. Journal of Counseling Psychology, 49(2), 255-263. doi: 10.1037/0022-0167.49.2.255.

Depdiknas. (2008). Penataan pendidikan profesional konselor dan layanan bimbingan dan konseling dalam jalur pendidikan formal. Jakarta: Departemen Pendidikan Nasional.

Dollarhide, C. T., Shavers, M. C., Baker, C. A., Dagg, D. R., \& Taylor, D. T. (2012). Conditions that create therapeutic connection: A phenomenological study. Counseling and Values, 57(2), 147-161. doi: 10.1002/j.2161-007X.2012.00014.x.

Egbochuku, E. O. (2010). Counseling communication skills: Its place in the training programme of a counseling psychologist. Edo Journal of Counseling, 1(1), 17-32. doi: 10.4314/ejc.v1i1.52380.

Elliot, R. G. (2011). When values and ethics conflict: the counselor's role and responsibility. Alabama Counseling Association Journal, 37(1), 39-45.

Farber, B. A., \& Doolin, E. M. (2011). Positive regard and affirmation. In J. C. Norcross (Ed.), Psychotherapy relationships that work: Evidencebased responsiveness 2nd ed. (pp. 168-186). New York, NY: Oxford University Press.

Feller, C. P., \& Cottone, R. R. (2003). The 
importance of empathy in the therapeutic alliance. Journal of Humanistic Counseling, Education and Development, 42(1), 53-61. doi: $10.1002 / \mathrm{j} .2164-$ 490X.2003.tb00168.x.

Fox, J. R. (2005). Transgender public clocking: Why do we stare? VISTAS Online, 42-55. Retrieved from https://www.counseling.org/docs/def aultsource/vistas/vistas_2005_vistas05art69.pdf?sfvrsn=7573236a_11.

Fuertes, J. N., \& Brobst, K. (2002). Clients' ratings of counselor multicultural competency. Cultural Diversity and Ethnic Diversity Psychology, 8(3), 214-233.

Fuertes, J. N., Stracuzzi, T. I., Bennett, J., Scheinholtz, J., Mislowack, A., Hersh, M., \& Cheng, B. (2006). Therapist multicultural competency: A study of therapy dyads. Psychotherapy: Theory, Research, Practice, Training, 43(4), 480-490. doi: 10.1037/0033-3204.43.4.480.

Gitimu, N. P. (2010). Intercultural communication: Its impotence to various career fields and perspective by various authors. Online Journal for Workforce Education and Development, 1(2), 1-13.

Greenberg, L. S., Watson, J. C., Elliot, R., \& Bohart, A. C. (2001). Empathy. Psychotherapy: Theory, Research, Practice, Training, 38(4), 380-384. doi: 10.1037/0033-3204.38.4.380.

Hair, J. F., Black, W. C., Babin, B. J., Anderson, R. E., \& Tatham, R. L. (2006). Multivariate data analysis (Vol. 6). Upper Saddle River, NJ: Pearson Prentice Hall.

Hansen, T. J. (2007). Epistemic contradictions in counseling theories: Implications for the structure of human experience and counseling practice. Counseling and Values, 51, 111-124.

Hauser, M., \& Hays, D. G. (2010). The slaying of a beautiful hypothesis: The efficacy of counseling and the therapeutic process. The Journal of Humanistic Counseling, Education, and Development, 49(1), 32-44. doi: $10.1002 / \mathrm{j} .2161-$ 1939.2010.tb00085.x.

Hays, P. A. (2008). Addressing cultural complexities in practice: Assessment, diagnosis, and therapy. Washington, DC: American Psychological Association.

Hill, E. C., Spigel, B. S., Hoffman, A. M., Kivlighan, Jr., M. D., \& Gelso, J. C. (2017). Therapist expertise in psychotherapy revisited. The Counseling Psychologist, 45(I), 753. doi: $10.1177 / 0011000016671006$.

Horvath, A. O. (2000). The therapeutic relationship: From transference to alliance. Journal of Clinical Psychology, 56(2), 163-173. doi: 10.1002/(SICI)10974679(200002)56:2<163::AIDJCLP3>3.0.CO;2-D.

Hogan, M. (2012). The four skills of cultural diversity competence. California: Cengage Learning.

Inman, A. G. (2006). Supervisor multicultural competence and its relation to supervisory process and outcome. Journal of Marital and Family Therapy, 32(1), 73-85. doi: 10.1111/j.17520606.2006.tb01589.x.

Ivey, A. E., Ivey, M. B., \& Zalaquett, C. P. (2013). Intentional interviewing and counseling: Facilitating client development in a multicultural 
society. Nelson Education.

Kastberg, S. M., Jordan, R. A., Kiweewa, J. M., \& Clingerman, T. (2014). Counselor as client: Emerging answers and new questions. The Practitioner Scholar: Journal of Counseling and Professional Psychology, 3(1), 1-16. doi: 10.1080/21507686.2010.493204.

Lambert, M. J., \& Barley, D. E. (2002). Research summary on the therapeutic relationship and psychotherapy outcome. In J. C. Norcross (Ed.), Psychotherapy relationships that work: therapist contributions and responsiveness to patients (pp. 17-32). New York, NY: Oxford University Press.

Lee, B. K. (2002). Development of a congruence scale based on the Satir model. Contemporary Family Therapy, 24(1), 217-239. doi: 10.1023/A:1014390009534.

Leibert, T. W., \& Dunne-Bryant, A. (2015). Do common factors account for counseling outcome? Journal of Counseling \& Development, 93(2), 225-235. doi: 10.1002/j.15566676.2015.00198.x.

Lubis, B. D. (2011). Understanding that heals. Malang: Alta Pustaka.

Mancillas, A. (2006). Counseling students' perceptions of counseling effectiveness. Vistas: Compelling Perspectives on Counseling, 191194.

Moon, K. A. (2007). A client-centered review of rogers with Gloria. Journal of Counseling and Development. doi: 10.1002/j.15566678.2007.tb00475.x.

NCGE. (2011, March). Counseling competences statement. Retrieved from

http://www.ncge.ie/uploads/Counseli ng_Competences_Statement.pdf.

Orlinsky, D. E., \& Ronnestad, M. H. (2005). Theoretical integration: Cycles of work and development. In D. E. Orlinsky, \& M. H. Ronnestad (Eds.), How psychotherapists develop: A study of therapeutic work and professional growth (161-180). Washington, DC: American Psychological Association.

Owen, J., \& Hilsenroth, M. J. (2014). Treatment adherence: The importance of therapist flexibility in relation to therapy outcomes. Journal of Counseling Psychology, 61(2), 280-288. doi: $10.1037 / \mathrm{a} 0035753$.

Penn, S. L., \& Post, P. B. (2012). Investigating various dimensions of play therapists' self-reported multicultural counseling competence. International Journal of Play Therapy, 21(1), 14-29. doi: $10.1037 / \mathrm{a} 0026894$.

Reinkraut, R., Motulsky, S. L., \& Ritchie, J. (2009). Developing a competent practitioner: Use of self in counseling psychology training. Asian Journal of Counseling, 16(1), 7-29.

Ridge, S., Campbell, W., \& Martin, D. (2003). Can an experience of conscious identification affect a counsellor's ability to sense and communicate unconditional positive regard? Theoretical and practicebased concerns. British Journal of Guidance \& Counseling, 31(3), 275288. doi: 10.1080/0306988031000147893.

Rogers, C. R. (1957). The necessary and 
sufficient conditions of therapeutic personality change. Journal of Consulting Psychology, 21(2), 95103. doi: $10.1037 / \mathrm{h} 0045357$.

Swank, J. M., Robinson, E. H., \& Ohrt, J. H. (2012). Manifestation of altruism: Perceptions among counseling students in the United Kingdom. Counseling and Psychotherapy Research, 12(1), 63-70. doi: 10.1080/14733145.2011.562981.

Swank, J. M., Lambie, G. W., \& Witta, E. L. (2012). An exploratory investigation of the counseling competencies scale: A measure of counseling skills, dispositions, and behaviors. Counselor Education and Supervision, 51(3), 189-206. doi: 10.1002/j.1556-6978.2012.00014.x.

Sawyer, C., Peters, M., \& Willis, J. (2013). Self-efficacy of beginning counselors to counsel clients in crisis. The Journal for Counselor Preparation and Supervision, 5(2), 30-43. doi: 10.7729/52.0042.

Sweeney, A., Fahmy, S., Nolan, F., Morant, N., Fox, Z., Lloyd-Evans, B., ... Johnson, S. (2014). The relationship between therapeutic alliance and service user satisfaction in mental health inpatient wards and crisis house alternatives: A crosssectional study. Plos One, 9(10), e100153. doi: 10.1371/journal.pone.0100153.

Sue, D. W., Arredondo, P., \& McDavis, R. J. (1992). Multicultural counseling competencies and standards: A call to the profession. Journal of Counseling \& Development, 70(4), 477-486. doi: 10.1002/j.15566676.1992.tb01642.x.
Sue, D. W., \& Sue, D. (2012). Counseling The culturally diverse: Theory and practice. New York, NY: Wiley.

Tracey, T. J. G., Wampold, B. E., Goodyear, R. K., \& Lichtenberg, J. W. (2015). Improving expertise in psychotherapy. Psychotherapy Bulletin, 50(1), 7-13.

Trusty, J., \& Brown, D. (2005). Advocacy competencies for professional school counselors. Professional School Counseling, 8(3), 259-265.

Van, W. J., Harmsen, J. \& Bruijnzeels, M. (2002). Intercultural communication in general practice. European Journal of Public Health, 12(1), 6368. doi: 10.1093/eurpub/12.1.63.

Wampold, B. E. (2011). Qualities and actions of effective therapists. Retrieved from https://www.apa.org/education/ce/eff ective-therapists.pdf.

Wilkins, P. (2000). Unconditional positive regard reconsidered. British Journal of Guidance and Counseling, 28(1), 23-36. doi: 10.1080/030698800109592.

Yager, G. G., \& Tovar-Blank, Z. G. (2007). Wellness and counselor education. Journal of Humanistic Counseling, Education, and Development, 46(2), 142- 153. doi: $10.1002 / \mathrm{j} .2161-$ 1939.2007.tb00032.x.

Zaharna, R. S. (2000). Intercultural communication and international public relations: Exploring parallels. Communication Quarterly. 48(1), 85-99. doi: 